\title{
Article
}

http://dx.doi.org/10.11646/phytotaxa.217.2.9

\section{Commiphora benguelensis (Burseraceae), a new species from Angola}

\author{
W. SWANEPOEL* \\ * H.G.W.J. Schweickerdt Herbarium, Department of Plant Science, University of Pretoria, Pretoria, 0002 South Africa. Postal address: \\ P.O.Box 21168, Windhoek, Namibia.E-mail:wessel@kaokosafari.com
}

\begin{abstract}
Commiphora benguelensis Swanepoel, described here as a new species, is known only from the Kaokoveld Centre of Endemism, southwestern Angola. It appears to be closely related to $C$. africana. Diagnostic morphological characters of $C$. benguelensis include the white, glutinous exudate, smooth bark and hairy, trifoliolate leaves. Illustrations of the plant and a distribution map are provided. Mainly confined to near the coast, the new species is widespread but uncommon between Namibe and Santa Maria.
\end{abstract}

\section{Introduction}

At present twelve described species of Commiphora Jacquin (1797: 66) are known from Angola. Five of these species are endemic to the Kaokoveld Centre of Endemism, a biogeographical region with many restricted-range plants and animals in southwestern Angola and adjacent northwestern Namibia (Mendes 1964, 1967; Van Wyk \& Smith 2001; Curtis \& Mannheimer 2005; Figueiredo \& Smith 2008). The Kaokoveld Centre is the principal focal point of diversity and endemism for Commiphora in southern Africa (Van Wyk \& Smith 2001) and new members of the genus continue to be discovered in this biologically diverse but botanically poorly explored region.

In this contribution, a new species of Commiphora from the Kaokoveld Centre is described. During a botanical expedition to southwestern Angola in April 2010, the author encountered an unfamiliar Commiphora with smooth, non-peeling bark and hairy, trifoliolate leaves, resembling C. africana (Richard 1831: 150) Engler (1883: 14) but with white, glutinous exudate (resin) and branches without spines. The plants were sterile at the time. During a subsequent visit in December 2010, flowers and fruit were collected. Plants were found in several localities on the coastal plain between Namibe and Santa Maria.

Live material of the new species was studied in the field, and morphological characters in the following description are based on mature leaves, fresh flowering material and ripe fruit. Diagnostic features for C. africana were determined through examination of plants in the field in southwestern Angola and in Namibia. Additional information for $C$. africana was sourced from the literature (Van der Walt 1986; Van der Walt \& Van der Schijff 1973; Steyn 2003; Swanepoel 2008).

\section{Taxonomic treatment}

Commiphora benguelensis Swanepoel, sp. nov. (Fig. 1)

Differs from $C$. africana in being dioecious or monoecious ( $v s$. dioecious); spineless ( $v s$. spinescent); exudate glutinous, white ( $v s$. not glutinous, clear); leaves trifoliolate, usually with few simple ones also present (vs. invariably trifoliolate), leaflets pilose adaxially, tomentose abaxially (vs. pilose to tomentose (in southern Africa), similar on both sides); flowers sessile ( $v s$. pedicellate); disc not grooved on inside, lobes bifid ( $v s$. disc grooved on inside, lobes simple); fruit with exocarp pilose (vs. glabrous); pseudo-aril yellow, with two short lobes and two long commissural arms (vs. red with 4 arms of variable size and form, or pseudo-aril almost completely covers the putamen).

Type:-ANGOLA. Namibe Province: 22 km SSE of Chapeu Armado in maritime hills, 1412CB, 438 m, 16 April 2010, Swanepoel 324 (holotype PRU!; isotype LUBA!). 

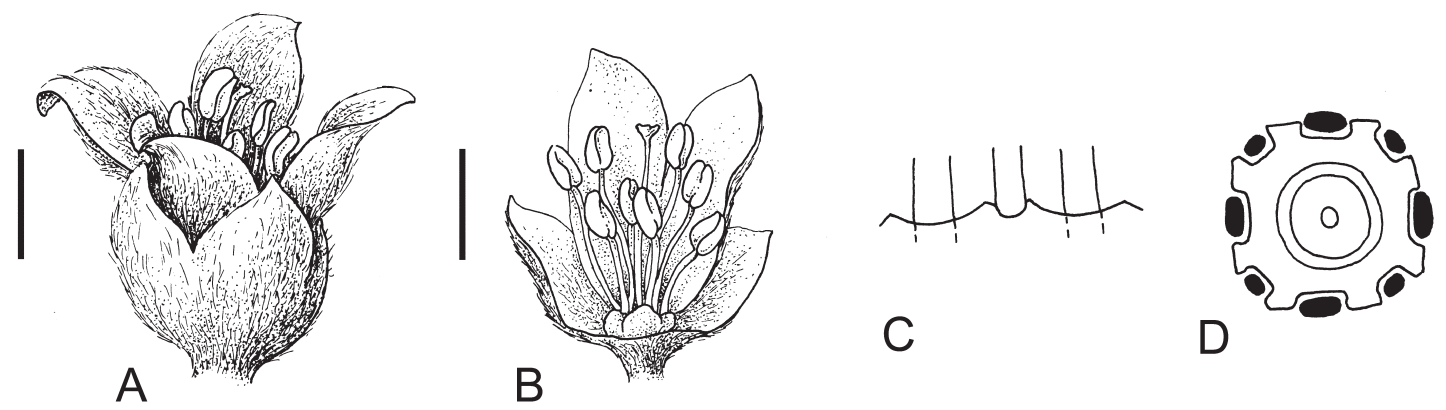

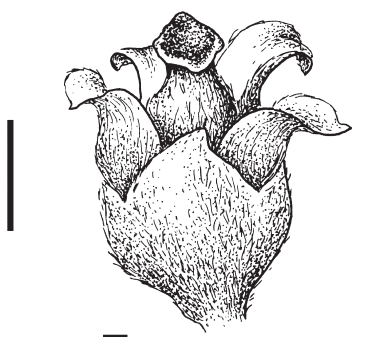

E

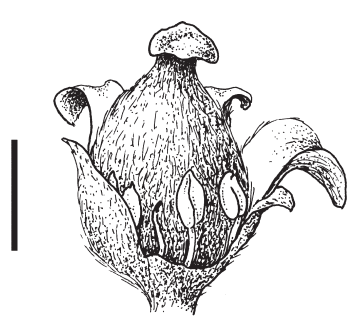

F
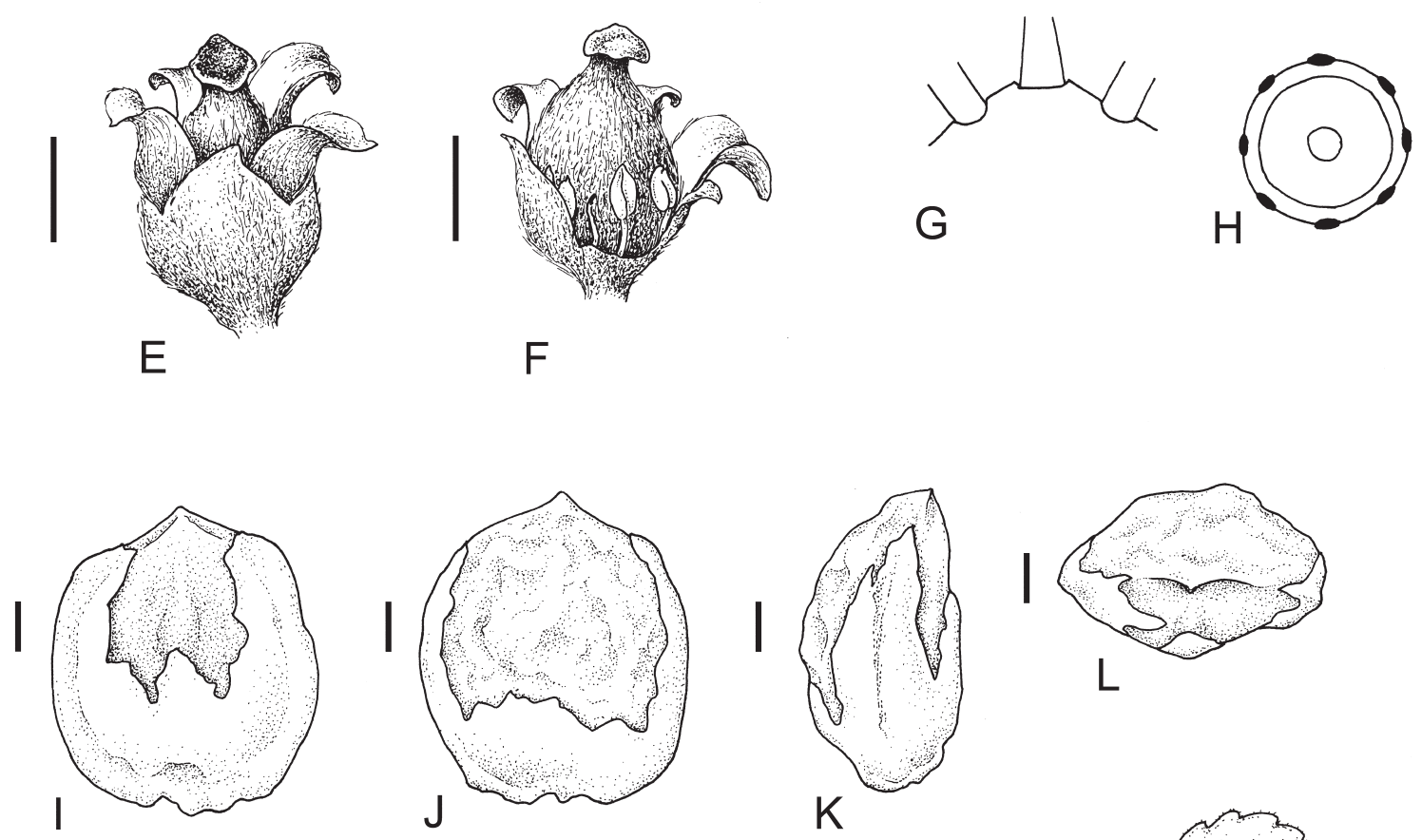

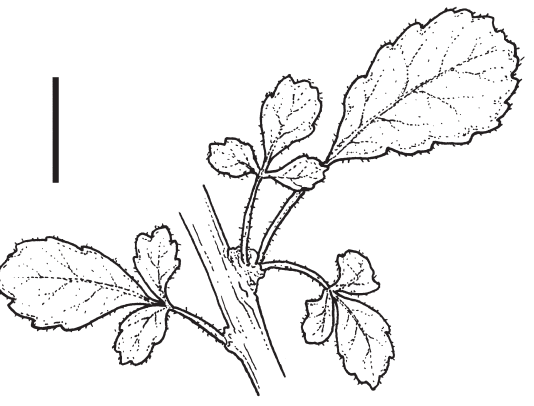

M

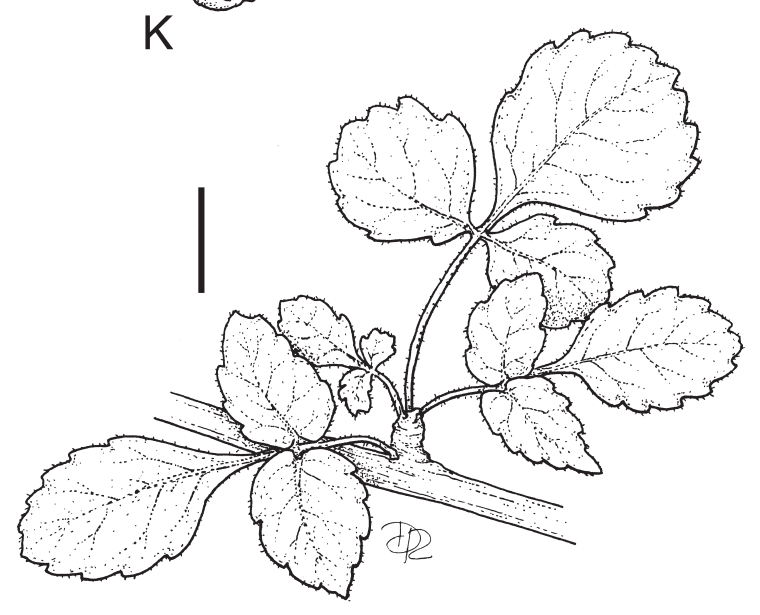

N

FIGURE 1. Commiphora benguelensis. Flowers, seed and leaves. (A-D) Male flower; (B) with calyx and corolla partly removed, showing stamens; (C) disc as seen from the inside (schematic); (D) disc as seen from above (schematic). (E-H) Female flower; (F) with calyx and corolla partly removed, showing pistil and rudimentary stamens; (G) disc as seen from the inside (schematic); (H) disc as seen from above (schematic). (I-L) Putamen with cupular pseudo-aril; (I) sterile locule; (J) fertile locule; (K) sutural view, fertile locule left, sterile locule right; (L) apical view. (M \& N) Leaves; (M) branch with trifoliolate and simple leaves; (N) branch with trifoliate leaves only. Scale bars (A \& B) $1 \mathrm{~mm},($ E \& F) $1 \mathrm{~mm}$, (I-L) $1 \mathrm{~mm},(\mathrm{M} \&$ N) $10 \mathrm{~mm}$. Artist: Daleen Roodt. Vouchers: leaves from Swanepoel 324, female flowers and seed from Swanepoel 328, male flowers from Swanepoel 329. 
Dioecious or monoecious shrub-like tree up to $2.5 \mathrm{~m}$ tall, $1-5 \mathrm{~m}$ diam. Trunk simple and short, up to $0.3 \mathrm{~m}$ long, $0.2 \mathrm{~m}$ diam., or branching repeatedly above ground level, appearing succulent. Bark beige, grey or green-grey with black spots in places, on branchlets brown, grey-brown or reddish brown. Branches and branchlets glabrous with few small, prominent lenticels; young growth pilose; dwarf lateral branchlets scarred. Exudate white, viscous, drying to form a soft, pale yellow, translucent resin. Leaves mostly trifoliolate, usually few simple ones also present, clustered on branches and on dwarf lateral branchlets but spirally arranged on actively elongating shoots, petiolate, green, indumentum white; lamina in simple leaves obovate or suborbicular, apex acute or obtuse, base cuneate or obtuse, 4-25 $\times 4-18 \mathrm{~mm}$; terminal leaflets in trifoliolate leaves subsessile or with petiolule up to $5 \mathrm{~mm}$ long, lamina obovate, elliptic, suborbicular or obcordate, apex rounded, truncate or retuse, base cuneate or cuneate-attenuate, 9-35 × 7-24 $\mathrm{mm}$, lamina of lateral leaflets obovate, elliptic or suborbicular, often asymmetric, apex rounded, obtuse or acute, base cuneate, rounded, obtuse or truncate, 4-18 $\times 3-13 \mathrm{~mm}$; simple and trifoliolate leaves with margins coarsely crenate-serrate or dentate-serrate in distal half, crenate or dentate towards apex, entire towards base, often revolute, lamina densely pilose adaxially, tomentose abaxially, with scattered, short glandular hairs on both sides, midrib and lateral veins prominent and conspicuous on both sides, petiole densely pilose with short glandular hairs, grooved adaxially, 3-24 mm long, pentagonal in transverse section with 5 vascular bundles, sectional dimensions $0.8-1.0$ $\times 0.8-1.2 \mathrm{~mm}$. Inflorescences: flowers axillary, solitary or clustered. Flowers precocious, unisexual, hypogynous, sessile. Bracts ovate or semi-circular, 0.3-0.6 mm long, densely pilose abaxially. Calyx pale green, densely pilose abaxially, glabrous adaxially or with few scattered hairs, lobes triangular, acute. Petals elliptic, broadly lanceolate or broadly oblanceolate, cream-coloured, pilose abaxially, glabrous or sparsely hairy towards apex adaxially, finely ciliate. Disc cylindrical with 4 distinct lobes, bifid at apex, not adnate to perianth. Male flowers $1.8-2.5 \mathrm{~mm}$ long, calyx 0.9-1.1 mm long, calyx lobes $\pm 0.6 \mathrm{~mm}$ long, petals $1.8-2.7 \times 0.9-1.1 \mathrm{~mm}$, spreading-ascending, minute tip inflexed; disc fleshy; stamens 8, filaments filiform, 4 long stamens with filaments $1.0-1.4 \mathrm{~mm}$ long, inserted on outer margin of disc lobes, 4 short stamens with filaments $0.6-0.9 \mathrm{~mm}$ long, inserted between lobes on outer margin of disc, anthers $0.7-0.9 \mathrm{~mm}$ long, all equal; gynoecium rudimentary, $\pm 0.5 \times 0.2 \mathrm{~mm}$. Female flowers $2-3 \mathrm{~mm}$ long, calyx $0.9-1.5 \mathrm{~mm}$ long, calyx lobes $0.6-0.8 \mathrm{~mm}$ long, petals $2.1-2.4 \times 0.9-1.1 \mathrm{~mm}$, ascending-spreading; staminodes 8 , alternately long and short, inserted on disc margin; ovary half-inferior, style relatively short, ovary and style densely pilose, stigma obscurely 4-lobed; pistil with stigma below top of flower (equal with calyx lobes), 1.2-1.5 × 0.9-1.1 mm. Fruit a drupe, subglobose or obovoid, slightly flattened, suture rectilinear, 6.8-8.8 $\times$ 7.4-8.4 $\times 6.2-7.1 \mathrm{~mm}$; pericarp 2-valved; exocarp densely pilose, cherry-red when ripe; mesocarp not very fleshy; putamen flattened, asymmetrical, rugose, subglobose or ellipsoid with one fertile and one sterile locule; $\pm 7.0 \times 5.5 \times 3.5 \mathrm{~mm}$; fertile locule \pm semi-circular in apical view; sterile locule slightly convex in apical view; suture rectilinear; angle between locules at apex $\pm 60^{\circ}$; pseudo-aril yellow, cupular, covering $\pm 30 \%$ of putamen, with short convex facial lobe on fertile locule and triangular lobe on sterile locule, commissural arms broad, almost reaching apical pits, part of pseudo-aril on fertile locule narrow, broad on sterile locule; apical pits small.

Phenology:-Commiphora benguelensis flowers in November and December. Fruits were encountered on plants in December.

Distribution and habitat:-Commiphora benguelensis is presently known from various localities in the coastal zone of southwestern Angola, from Namibe to $\pm 40 \mathrm{~km}$ inland and northwards to Santa Maria (Fig. 2). This arid area falls within the Kaokoveld Centre of Plant Endemism (Van Wyk and Smith, 2001) and is part of the Namib Desert. $C$. benguelensis is uncommon and occurs with several other species of Commiphora on mountain slopes and level areas, in arid bushveld and desert shrubland at elevations of 50-600 m.

Conservation status:-Commiphora benguelensis is not under any threat as the plants are located in remote, sparsely populated areas.

Etymology:-The specific epithet refers to the Benguela Current of the Atlantic Ocean which plays a major role in maintaining the arid climatic conditions of the bordering Namib Desert and the Kaokoveld Centre (Seely 2004). The Benguela Province, one of the two politically demarcated provinces of Angola in which the new species occurs, is also named after the Benguela Current.

Notes:-Commiphora benguelensis can be confused with C. africana, with which it shares a similar habit and non-peeling bark (at least where the two taxa are sympatric), pilose young branches, hairy, trifoliolate leaves and hypogynous flowers. Commiphora benguelensis differs from C. africana in several characters of the habit, exudate, leaves, flowers, and fruit.

Some of the more prominent morphological features to differentiate $C$. benguelensis from C. africana are compared in Table 1. 


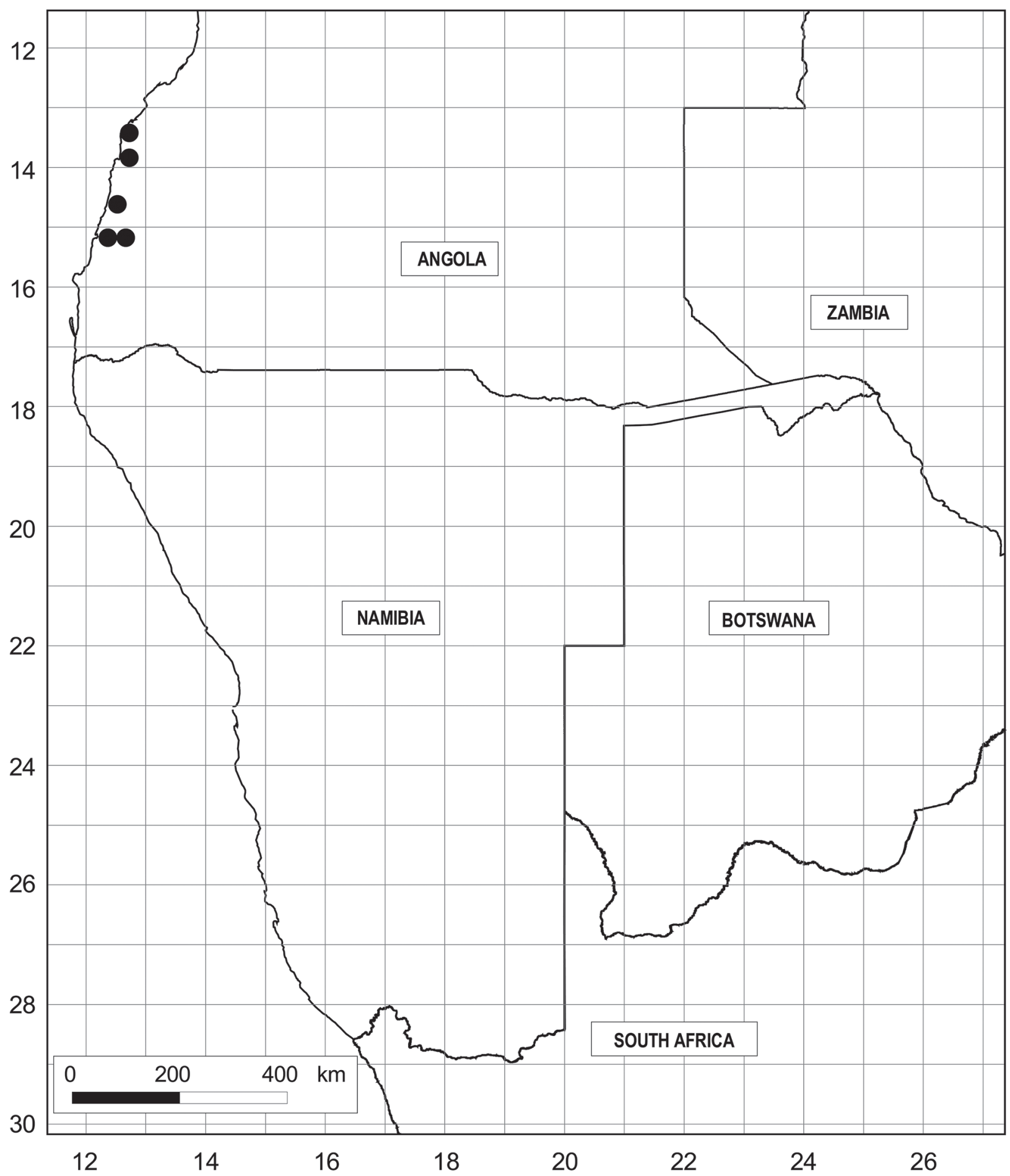

FIGURE 2. Known distribution of Commiphora benguelensis.

\section{Additional specimens examined (paratypes):}

ANGOLA, Benguela Province:

-1312: Along track to Meva, (-BC), 327 m, 25 April 2010, Swanepoel 327 (PRU!).

ANGOLA, Namibe Province:

—1312: 2 km south of Lucira along access road, (-DC), 55 m, 18 April 2010, Swanepoel 325 (PRU!); 9 km from main road on track to Chicambi, (-DC), 583 m, 18 April 2010, Swanepoel 326 (PRU!). 
—1512: $29 \mathrm{~km}$ west of Caraculo along main road to Namibe, (-AB), $321 \mathrm{~m}, 15$ April 2010, Swanepoel 323 (PRU!); 13 $\mathrm{km}$ west of Caraculo along main road to Namibe, (-BA), 526 m, 14 April 2010, Swanepoel 322 (PRU!).

TABLE 1. Comparative table of the more prominent differences between Commiphora benguelensis and C. africana.

\begin{tabular}{|c|c|c|}
\hline Character & C. benguelensis & C. africana \\
\hline Habit & $\begin{array}{l}\text { Dioecious or monoecious shrub-like tree up to } \\
2.5 \mathrm{~m} \text { tall }\end{array}$ & $\begin{array}{l}\text { Dioecious, many-stemmed shrub usually } \\
\text { less than } 1 \mathrm{~m} \text { tall, or small tree with single } \\
\text { trunk up to } 4 \mathrm{~m} \text { tall }\end{array}$ \\
\hline Branches and branchlets & Spineless & Spinescent \\
\hline Exudate (resin) & White, glutinous & Clear, not glutinous \\
\hline Leaves & Mainly trifoliolate, few simple & Trifoliolate \\
\hline Lamina shape ( terminal leaflets) & Elliptic, suborbicular or obcordate & Elliptic or obovate (in southern Africa) \\
\hline Lamina shape (lateral leaflets) & Elliptic, suborbicular or obovate & Elliptic or obovate (in southern Africa) \\
\hline Indumentum & Densely pilose adaxially, tomentose abaxially & $\begin{array}{l}\text { Pilose to tomentose (in southern Africa), } \\
\text { similar on both sides }\end{array}$ \\
\hline \multicolumn{3}{|l|}{ Petiole } \\
\hline Shape in $t / s$ & Pentagonal & Triangular \\
\hline Number of vascular bundles & 5 & $7-9$ \\
\hline Flowers & Sessile & Pedicellate \\
\hline Calyx and petals (indumentum) & Pilose abaxially & Glabrous (in southern Africa) \\
\hline Disc & Not grooved on inside, lobes bifid & Grooved on inside, lobes simple \\
\hline Fruit (exocarp surface) & Pilose & Glabrous \\
\hline Pseudo-aril & $\begin{array}{l}\text { Yellow, with two short lobes and two long } \\
\text { commissural arms }\end{array}$ & $\begin{array}{l}\text { Red, with four arms of variable size and } \\
\text { form, or almost completely covering the } \\
\text { putamen }\end{array}$ \\
\hline Distribution & $\begin{array}{l}\text { Confined to Kaokoveld Centre of Endemism in } \\
\text { southwestern Angola }\end{array}$ & $\begin{array}{l}\text { Polymorphic species, widespread in sub- } \\
\text { Saharan Africa except extreme southern } \\
\text { parts of continent }\end{array}$ \\
\hline
\end{tabular}

\section{Acknowledgements}

I would like to thank Prof. Abraham E. van Wyk for advice and support, Ms Hester Steyn for preparing the distribution map and Ms Daleen Roodt for the line drawings. The curator, National Herbarium (PRE), Pretoria, is thanked for access to their collections; the assistance of Ms Marie Jordaan is acknowledged with thanks. The University of Pretoria is thanked for financial support. I am indebted to Mr Eduardo Traguedo for logistical support in Angola. For assistance and companionship during field trips, I am especially grateful to my wife Hannelie, friends Ernst van Jaarsveld and Tielman Haumann. 


\section{References}

Curtis, B.A. \& Mannheimer, C.A. (2005) Tree atlas of Namibia. National Botanical Research Institute, Windhoek, 674 pp.

Engler, A. (1883) Burseraceae. In: De Candolle, A. \& De Candolle C. (Eds.) Monographiae phanerogamarum prodromi nunc continuato, nunc revisio, vol. 4. G. Masson, Paris, pp. 1-169 \& pp. 536-540.

http://dx.doi.org/10.5962/bhl.title.45961

Figueiredo, E. \& Smith, G.F. (2008) Plants of Angola/Plantas de Angola. Strelitzia 22, 1-279.

Jacquin, N.J. (1797) Plantarum rariorum horti caesarei Schoenbrunnensis, vol. 2. C.F. Wappler, Vienna, pp. 1-68 \& pls.130-250. http://dx.doi.org/10.5962/bhl.title.332

Mendes, E.J. (1964) Additiones ed adnotationes florae angolensi - VIII. Boletim da Sociedade Broteriana, sér. 2 38: 137-138.

Mendes, E.J. (1967) Additiones ed adnotationes florae angolensi - X. Boletim da Sociedade Broteriana, sér. 2 41: $155-164$.

Richard, A. (1831) Terebinthaceae. In: Guillemin, J.A., Perrottet, S. \& Richard, A. (Eds.) Florae Senegambiae tentamen, seu, historia plantarum in diversis Senegambiae regionibus a peregrinatoribus Perrottet et Leprieur detectarum, vol. 1. Paris, Treuttel \& Wurtz, pp. $147-156$.

http://dx.doi.org/10.5962/bhl.title.595

Seely, M. (2004) The Namib: natural history of an ancient desert. Desert Research Foundation of Namibia, Windhoek, 110 pp.

Steyn, M. (2003) A field guide, southern Africa Commiphora / 'n Veldgids, Suider-Afrika Commiphora. Published by the author, Polokwane, $92 \mathrm{pp}$.

Swanepoel, W. (2008) Commiphora otjihipana (Burseraceae), a new species from the Kaokoveld, Namibia. South African Journal of Botany 74: 623-628.

http://dx.doi.org/10.1016/j.sajb.2008.03.001

Van der Walt, J.J.A. (1986) Burseraceae. Flora of southern Africa 18: 5-34.

Van der Walt, J.J.A. \& Van der Schijff, H.P. (1973) The anatomy of the petiole as an aid to the identification of South African Commiphora species. Kirkia 9: 95-108.

Van Wyk, A.E. \& Smith, G.F. (2001) Regions of floristic endemism in southern Africa: a review with emphasis on succulents. Umdaus Press, Hatfield, Pretoria, 199 pp. 